Centre for Law, Economics and Society

CLES

Faculty of Laws, UCL

Director: Dr. Ioannis Lianos

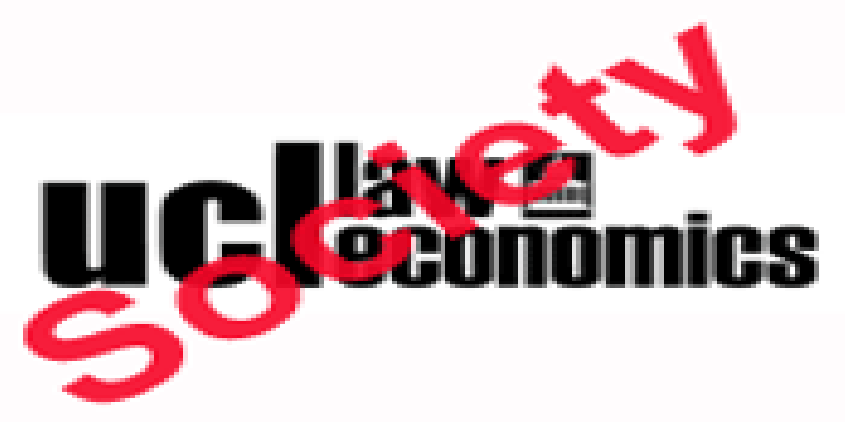

CLES Working Paper Series

$3 / 2012$

\title{
Towards a bureaucracy theory of the interaction between competition law and state action
}

\author{
Ioannis Lianos
}

September 2012 


\section{Introduction}

Competition law and economics literature has always thought of the relation between the principle of competition and government action in antagonistic terms. According to the Chicago school of antitrust economics, state action or government induced action is considered as the most frequent source for restrictions of competition. ${ }^{1}$ Public choice theories have also cast doubt on the motivations of state action, thus contributing with the Chicago school of economic analysis to lay the foundations of a distinct theory of government failure, with the aim to marginalize government, which completes the market failure dominated theories of neo-classical economics ${ }^{2}$. The perception that the state constitutes a natural monopoly, with the ability to coerce any economic provider operating in its territory to adopt and maintain anticompetitive conduct for an indefinite period of time, without any challenge, has formed the core claim of the deregulation agenda worldwide. The anti-competitive effects of government action can even be felt post-liberalization with a number of entrenched dominant positions by former monopoly incumbents being preserved through anticompetitive conduct. Some authors have even characterised public restraints as a global limit to competition law, calling for an active enforcement of competition law against government action that benefits special interests. ${ }^{3}$ In contrast, others have argued that "the democratic process contains many flaws, but curing them is no antitrust's assignment" and that "if Congress wanted to draft anti-capture legislation it could do so, but one would hardly imagine that this legislation would forbid monopoly or combinations in restraint of trade while explicitly saying nothing about abuses of governmental process", and have advanced a more limited role for antitrust in the process of "democratic government". 4

These different perspectives illustrate the complexity of the matter as it is unclear how and to what extent the different variables authors usually take into account when confronting "competition law" with "state" action (the "democratic process", "private interests", "public" versus "private" restraints, "special" versus "general" interests) are interlinked with each other, and/or if they should be analysed separately. For example, in the absence of a proper "democratic process", should antitrust always apply in order to preserve some form of market competition, the assumption being that in the absence of electoral competition, market or "quasimarket" (in the case of an administered economy) competition is the only option left to promote efficiency, the latter concept conceived as policies corresponding to citizens' (for the purpose of political competition) or consumers' (for the purposes of

\footnotetext{
${ }^{1}$ See, Milton Friedman, Capitalism and Freedom (1962), Chapter II .

${ }^{2}$ Stephen G. Medema, The Hesitant Hand: Taming Self-Interest in the Histiry of Economic Ideas (2009), Chapters 4-6..

${ }^{3}$ D. Daniel Sokol, Anticompetitive Government Regulation, in The Global Limits of Competition Law 83 (Ioannis Lianos \& Daniel Sokol ed. 2012) ; D. Daniel Sokol, Limiting Anti-Competitive Government Interventions That Benefit Special Interests, 17 George Mason Law Review 119 (2009).

${ }^{4}$ Herbert Hovenkamp, Federal Antitrust Policy $\left(4^{\text {th }}\right.$ ed., 2011), p. 747; Einer Elhauge, The scope of antitrust process, 104 Harvard L Rev 667 (1991).
} 
market competition) preferences ${ }^{5}$ How would one go about addressing the distinction between "public" and "private" restraints, when the enforcement mechanism of the state is frequently used to orchestrate "private" restraints of competition"? Would the distinction between "public" and "private" or that of "political" versus "market" competition always hold, when it is possible that restrictions of market competition may be traded for political support (power) and thus limit electoral competition or when governments frequently act through private actors?

An underlying assumption, common to these perspectives, is that the "state" is juxtaposed to the "market", the two forming different conceptual categories, having a defined timeless meaning across different cultures. There is no effort to explore inside the black-box of the "State" and understand the operation of the different branches of power, their internal bureaucracies, the beliefs of the agents whose actions comprise the phenomena to be explained, or their interaction within a specific society; at most, there is a one-dimensional effort to apply to the state a markets-inspired analysis. Nonetheless, if public choice theory applies to political science analysis the conceptual framework of markets, it has not adequately taken into account the input of the political science or political sociology literature on the concept of "state", when this does not share the rational choice model preferred by economists ${ }^{7}$. Yet, this literature may offer useful insights. For example, a predominantly patrimonial state sets very different challenges for competition law enforcement and regulation, more broadly, than a neo-liberal or neo-corporatist one: one size does not fit all ${ }^{8}$. At the same time, it is important to acknowledge the different disciplinary and cultural identities of bureaucracies or "technocracies" involved in governmental decision making, and their evolution, in particular as competition law can also be envisioned as having always been (e.g. Europe) or having evolved to (e.g. United States) a technocratic discipline. ${ }^{9}$

This chapter challenges the traditional antagonistic conception of the interaction between competition law and the State, by advancing the need to examine in depth the nature of government bureaucracies involved in decision-making and their respective claims for expertise and legitimacy. The analysis focuses on the context of a neo-liberal state, as it can provide useful insights on the erosion of the

\footnotetext{
${ }^{5}$ Chicago authors may support this statement in view of their conception of the relations between political and economic freedom: see, Milton Friedman, op. cit., p. 10 ("it is therefore clearly possible to have economic arrangements that are fundamentally capitalist [preserving economic freedom] and political arrangements that are not free").

${ }^{6}$ E.g. Case T-321/05 AstraZeneca AB and AstraZeneca plc v. European Commission [2010] ECR II2085 (abuse of procedures relating to supplementary protection certificates for medicinal products) and the vexatious (sham) litigation theory in EU and US competition law.

${ }^{7}$ See, for instance the criticisms to public choice by political scientists advancing a more pluralistic research agenda: Donald Green \& Ian Shapiro, Pathologies of Rational Choice Theory: A Critique of Applications in Political Science (1994).

${ }^{8}$ Max Weber, Economy and Society 1041 (1978) defines "patrimonial state" as one where "practically everything depends explicitly upon personal considerations: Upon the attitude towards the concrete applicant and his concrete request and upon purely personal connections, favors, promises and privileges". These distinctions are of course ideal types, as in reality some of the characteristics of each form of State may co-exist for a certain time.

${ }^{9}$ Daniel A. Crane, Technocracy and Antitrust, 86 Texas L Rev 1159 (2008).
} 
state/markets binarity and the interaction of competition law with government activity. A different analysis may apply to other forms of states, but this is not within the scope of this study.

\section{Unveiling the concept of the State: government bureaucracy and the principle of competition in the neo-liberal tradition}

In a liberal state, the power of government to regulate market activity is limited: first, by a set of principles external to the government, such as the concept of natural law or the theory of the social contract between the sovereign and its subjects, from which basic rights were derived, thus delimiting "the domain of possible governmentality" from the domain of fundamental freedoms (on the basis of a "juridico-deductive approach" ${ }^{\prime 10}$ ); second, by the emergence of an internal rationality of governmental practice, in essence, the new discipline of political economy and the philosophy of utilitarianism. These new "technologies of government" set limitations on governmental reason by separating the sphere of intervention of public authorities from that of individual independence or autonomy, the foundations of the market system.

Yet, there is an essential difference between these two approaches:

"(p)olitical economy reflects on governmental practices themselves, and it does not question them to determine whether or not they are legitimate in terms of right. It considers them in terms of their effects rather than their origins". ${ }^{11}$

Hence, governmental action is not only subject to the binary distinction of legitimate/not legitimate but also to the distinction of true/false, introduced by political economy, the market becoming a site of "veridiction-falsification" for governmental practice. This is based on the assumption that

" [...] inasmuch as prices are determined in accordance with the natural mechanisms of the market they constitute a standard of truth which enables us to discern which governmental practices are correct and which are erroneous." 12

Classical liberalism conceived the role of the state as supportive of the principle of individual autonomy; its only precept was for the state not to intervene, with the exception of rules guaranteeing some minimum standards for an equitable exchange (e.g. absence of fraud and coercion in contracts). Yet, the gradual building of a welfare state as a response to the social consequences of the Great Depression was the historical setting of this expansion of the role of government and led to some intense governmental intervention in the market. The neoclassical price theory of market failure and Keynesian economics were its intellectual backbones. But more

\footnotetext{
${ }^{10}$ Michel Foucault, The Birth of Biopolitics - Lectures at the Collège de France 1978-1979, 39 (2010, first published 1979).

${ }^{11}$ Ibid., p. 15.

${ }^{12}$ Ibid., p. 32.
} 
importantly, the rise of government bureaucracy offered the appropriate tool, the technology, for that expansion to occur. The role of government in markets is thus closely related to the development of the professional project of public bureaucracies, as the state has no essence other than "the mobile effect of a regime of multiple governmentalities" $" 13$ The State is not a universal, nor is it an autonomous source of power. It is only the "effect" of a "perpetual statification" of multiple organized practices (mentalities, rationalities, techniques and strategies) through which subjects are governed. The State should thus be viewed via the analysis of practices of "governmentality", hence our focus on government bureaucracies.

The "technization" of the State through bureaucracy gave birth to a different form of legitimacy. ${ }^{14}$ Bureaucracy is based on hierarchical and functional organization, clearly defined areas of expertise, standard operating procedures, and fixed roles descriptions. The essential assumption of the bureaucratic form of organization is that bureaucrats identify their own interest and ideas with the organization of which they are part. Bureaucracy is thus perceived positively, a view profoundly linked to the image of professional expertise and political neutrality that is attached to it. As all large-scale organizations, the State tends to be bureaucratic in nature. The expansion of bureaucracy is thus inevitable and profoundly linked to the expansion of the State (in a chicken and egg way), as it is the only way of coping with the administrative requirements of large-scale social systems.

One of the main characteristics of bureaucracy is the clear-cut hierarchy of authority, with a chain of command stretching from the top to the bottom, the existence of clear rules on the conduct of officials at all levels of government, the existence of a clear career path based on seniority, the separation from politics and ideology as the focus is on means and procedural rituals, rather than on policy outcomes. This contrasts with the heterarchical dimension of the "market", where individual entrepreneurs enjoy property rights on the means of production and compete with each other. This analysis may apply to both administrative (government) and industrial (private sector) bureaucracies, which present some common characteristics, although the first one benefits from a total absence of competition, because of the monopoly power enjoyed by the government and the development of a professional public bureaucracy, not subject to the vagaries of electoral or party competition.

In conclusion, bureaucracy is seen as an essential step in the reconceptualization of the role of the state, according to the principle of rationality. It is perceived as a form of sophisticated technology enabling the state to intervene and regulate markets. In one of his classic texts, Max Weber notes:

"Bureaucracy offers above all the optimum possibility for carrying through the principle of specializing administrative functions according to purely objective considerations. Individual performances are allocated to functionaries who have specialized training and who by constant practice learn more and more.

\footnotetext{
${ }^{13}$ Ibid., p. 77.

${ }^{14}$ Ibid., p. 115.
} 
The 'objective discharge of business primarily means a discharge of business according to calculable rules and "without regard for persons". 15

This positive view of bureaucracy is intrinsically linked not only to the expansion of government's role in various areas, until then managed by market activity only, but also to the reinforcement of the institutional apparatus of the state, with the establishment of either central ministerial departments or of independent administrative agencies, during the same period, and in some jurisdictions of a specialized judiciary to deal with issues arising from the normative activity of state bureaucraties $^{16}$. In other words, the expansion of government's role in markets would not have been possible in the absence of the "technology" of professional public bureaucracy.

Yet, this positive account of bureaucracy was soon to be challenged by functionalist sociologists, such as Merton, Selznick and Crozier, among others. Merton emphasized the "dysfunctions of bureaucracy", stemming from bureaucratic ritualism and emphasis on procedures rather than on underlying organizational goals. ${ }^{17}$ Based on the "human relations approach to bureaucracy", Merton acknowledged the limits of Weber's ideal type, as the discipline necessary for obtaining the kind of standardized behaviour required in a bureaucratic organization may ultimately lead to a displacement of goals. This inflexibility of bureaucratic organizations and their over-specialisation impedes bureaucrats from innovating and from responding creatively to new challenges. The "vicious circle" of bureaucratization is further reinforced through a mechanism of co-optation and the diffusion of a special ideology securing the necessary minimum of conformity and loyalty to the organization. ${ }^{18}$ Crozier notes how the bureaucratic system of organization "is not only a system that does not correct its behaviour in view of its errors, it is also too rigid to adjust without crisis to the transformations that the accelerated evolution of industrial society makes more and more imperative". ${ }^{19}$

These criticisms of the bureaucratic state became even more pronounced with the emergence of neo-liberalism. It is possible to distinguish between two trends in neo-liberal thought, for the purposes of this short text: first, the development, partly in parallel with the theory of market failure, of the theory of government failure in welfare economics; second, the emergence in Germany of the ordo-liberal model of

\footnotetext{
${ }^{15}$ Max Weber, Economy and Society 975 (1978).

16 See, for instance, the establishment of the Conseil d'Etat in France in 1799 inaugurating the distinction between public and private law in some Continental European legal traditions, an influential model still today. The aim was to exclude from the scope of ordinary general courts the administrative functions of the state, hence providing more discretion to government bureaucracies. By focusing on the control of legality only and providing government discretion in complex economic and technical matters, administrative courts ensured that bureaucracy was acting according to the limits set to its rational-legal authority.

17 Robert Merton, The Unanticipated Consequences of Purposive Social Action, 1 American Sociological Review 894 (1936); Robert Merton, Bureaucratic Structure and Personality, in Social Theory and Social Structure 249-260 (Robert Merton ed., 1968).

${ }^{18}$ Michel Crozier, The Bureaucratic Phenomenon 186-187 (1964).

${ }^{19}$ Ibid., p. 195.
} 
neo-liberalism, which has profoundly marked the intellectual foundations of the European economic integration project.

The first story is too well known to be developed in detail: to Ronald Coase's virulent criticism of Pigou's theory of externalities, suggesting that the assessment of the performance of different institutions (firms, markets, regulation) should involve the comparison of alternative institutional arrangements, public choice theorists added the analysis of government from a rational choice perspective: "(g)overnment, like the market in a pure exchange economy, is viewed simply as an institution for aggregating or balancing individual demands for public policies". ${ }^{20}$ The implications of these two standpoints for government intervention in the economy are devastating. Once the supply of government policies is viewed as a proper market, the mechanisms of collective choice are built upon the following three articulations: (i) voters make political decisions in order to maximize their utility; (ii) lawmakers seek to maximize the votes they obtain and stay in office and (iii) voters are rational ignorants, as given that voting and informing oneself about policy is costly and that the benefit derived from an individual vote is zero, it is rational for them to remain uninformed about public policy. ${ }^{21}$ In view of the collective action problem for diffused and large group interests, smaller groups are more likely to win rents from the government and to capture policymakers. Consequently, regulation does not promote the public interest but the goals of powerful interest groups. The analysis has been transposed to nondirectly elected regulators, such as the executive (bureaucracy) and judicial branches of government, which, it has been noted, offer a more durable form of protection. ${ }^{22}$

The standard model relies on the fact that the nonmarket nature of government's outputs leads to a measurement problem, as it is not possible to define, as in a market system, the number of units of output produced as such, but only to report the level of activities, from which output levels may be inferred. This leads to a monitoring problem, where the purchaser of public services, e.g. the government operating as the agent of all citizens, cannot observe and thus monitor the bureaucrat's efficiency. This information asymmetry, because of the bureaucrat's expertise over his real costs, might be exploited by the bureaucrat, should he operate, as it is often the case, as a monopolist supplier. Indeed, the monopoly nature of most public service providers frees them from the competition process and does not enable the government (and thus ultimately the citizens) to dispose of an alternative source of information over the real costs of the provision of public services. The incentives of the bureaucrat are thus by nature in opposition to the public interest. As the bureaucrat's salaries are unrelated to improved efficiency, because of the monitoring problem, the bureaucrat does not pursue, as private business managers, profits but

\footnotetext{
${ }^{20}$ Dennis C. Mueller, Public Choice III 359 (2003).

${ }^{21}$ Jessica Leight, Public Choice: A Critical Reassessment, in Government and Markets - Towards a New Theory of Regulation 213-255 (Edward J. Balleisen \& David A. Moss ed. 2010).

${ }_{22}$ Mark W. Crain \& Robert Tollison, The Executive Branch in the Interest-Group Theory of Government, 8(1) Journal of Legal Studies 165 (1979); William Landes \& Richard Posner, The Independent Judiciary in an Interest-Group Perspective, 18(3) Journal of Law and Economics 875 (1975); Thomas W. Merrill, Capture Theory and the Courts: 1967-1983, 72 Chi.-Kent L. Rev. 1039 (1997).
} 
essentially non-pecuniary goals, the maximization of budget size and/or the expansion of the bureau's personnel and tasks, both leading to organizational slack and wasteful duplication of competences. ${ }^{23}$ Empirical studies have examined the comparative cost structures of private firms operating in a competitive environment and public monopolies, or undertakings partly controlled by the state, and found that the latter provided the fixed output demanded by the community at a higher cost than necessary. ${ }^{24}$

Yet, empirical evidence is inconclusive on the ability of citizens to control effectively government and bureaucracy and the possibility for democratic competition to produce "efficiency levels comparable to those achieved by market competition". ${ }^{25}$ Furthermore, most of the empirical backing of the public choice theory relies on correlations between some limited variables indicating capture to infer causation, without a proper falsifiable analysis of the impact of other variables than capture on the regulatory outcomes, such as ideology or structural and demographic characteristics. ${ }^{26}$ Finally, public choice theory mostly assumes a monopolistic setting with regard to the provision of public services,${ }^{27}$ without taking stock of electoral competition in democratic politics, and also competition coming from other institutions than the government, such as the not-for-profit sector, religious organizations, unions, corporations, families. ${ }^{28}$

The second is the ordoliberal version of neo-liberalism, particularly influential in Europe. Born in Germany in the 1930s, ordoliberalism was opposed to any variant of planned state interventionism, in whatever form: Bismarckian state socialism, Nazi autarchic planification or Keynesian-style interventionism. Attacking New Deal programmes or the Beveridge plan as symbols of the welfare state, ordoliberal authors emphasized the risks of state management of the economy, thus adhering partly to the government failure theory but also to the idea that the distinction between the "market" and the "state" is intellectually sterile. They advanced instead market economy as the principle and model for the State, which should be organized on the basis of the principle of competition. ${ }^{29}$ The research programme of the ordoliberals has been nicely summarized by Foucault:

\footnotetext{
${ }^{23}$ William Niskanen Jr., Bureaucracy and Representative Government (Chicago, 1971), Jean-Jacques Laffont \& Jean Tirole, The Politics of Government Decision-Making: A Theory of Regulatory Capture, 106(4) Quarterly Journal of Economics 1089 (1991).

${ }^{24}$ See, for instance, the studies listed by Dennis C. Mueller, Public Choice III 373-379.

${ }^{25}$ Ibid., p. 384; Donald Wittman, The End of Special Interests Theory and the Beginning of a More Positive View of Democratic Politics, in Government and Markets - Towards a New Theory of Regulation 193-212 (Edward J. Balleisen \& David A. Moss ed. 2010).

${ }^{26}$ Jessica Leight, op. cit.; Donald Green \& Ian Shapiro, Pathologies of Rational Choice Theory: A Critique of Applications in Political Science (1994); Einer R. Elhauge, Does Interest Group Theory Justify More Intrusive Judicial Review?, 101 Yale L.J. 31 (1991).

${ }^{27}$ Richard D. Auster \& Morris Silver, The State as a Firm (1979).

${ }^{28}$ Donald Wittman, op. cit., p. 207.

${ }^{29}$ Walter Eucken, The Foundations of Economics- History and theory in the analysis of economic reality (London, 1950); Hanz Rieter \& Matthias Schmolz, The ideas of German Ordoliberalism 19381945: pointing the way to a new economic order, 1(1) The European Journal of the History of Economic Thought 87 (1993).
} 
"Since it turns out that the state is the bearer of intrinsic defects, let's ask the market economy itself to be the principle, not of the state's limitations [as was the case in the liberal model], but of its internal regulation from start to finish of its existence and action. In other words, instead of accepting a free market defined by the state and kept as it were under state supervision - which was, in a way, the initial formula of liberalism: let us establish a space of economic freedom and let us circumscribe it by a state that will supervise it - the ordoliberals say we should completely turn the formula around and adopt the free market as organizing and regulating principle of the state, from the start of its existence up to the last form of its interventions. In other words: a state under the supervision of the market rather than a market supervised by the state". 30

According to Foucault, ordoliberalism relied on three major shifts from the old liberal tradition: (i) a shift from the concept of exchange (which limited the role of the State to ensure respect for the freedom of those involved in the exchange, on the basis of the principle of laissez-faire) to that of competition (the state actively intervening in order to prevent a distortion of competition and the creation of monopolies); (ii) a shift from the perception of competition as a natural and pre-existing given to a view of complete competition as "an historical objective of governmental art", to be actively pursued by the state; (iii) a shift from the view of the relation between competition and the state as reciprocally delimited areas to that of a "complete superimposition of market mechanisms, indexed to competition, and governmental policy", the market constituting the "general index in which one must place the rule for defining all governmental action". ${ }^{31}$ The relation between competition/markets and the state is thus reversed, in comparison to the liberal model, without, however, leading to a new form of laissez-faire. It is important to understand here that the ordoliberal version of neo-liberalism argues that the competitive market order should be integrated at the constitutional level, and not at the sub-constitutional level, that of choosing policies. This constitutional dimension requires the institutional framing of market processes: the market being transformed into a constitutional order. Contrary to welfare economics, ordoliberal authors aim to enforce a competitive order in an indirect manner, framing the rules of the game, rather than seeking to improve the outcomes directly by way of specific interventions into the economic process. ${ }^{32}$

\section{Implications on the relation between government activity and the principle of competition: the role of bureaucracy}

These different traditions of neo-liberalism may have different implications for the relation between government activity and competition. If one adopts a public choice

\footnotetext{
${ }^{30}$ Michel Foucault, op. cit., p. 116.

${ }^{31}$ Ibid., pp. 119-121.

${ }^{32}$ Viktor J. Vamberg, The Freiburg School: Walter Eucken and Ordoliberalism (Freiburg Discussion Papers on Constitutional Economics, 04/11), p. 7.
} 
perspective, it is possible to argue that any form of state intervention in the marketplace carries the risk of capture and inefficiency: there is a wealth of empirical literature on the inefficiency of sector specific regulations, but similar claims have also been made with regard to competition law. ${ }^{33}$ The burden of proof is on the State to establish the need of its intervention through competition law, and the standard of proof is set high, on the assumption that the self-correcting mechanism of the market will take care of any eventual failure, in the absence of state interference. Such an approach leads essentially to subject state intervention to a stricter competition assessment than private action, as by essence the monolithic (and monopolistic) nature of government intervention departs more from the optimum of competitive markets (and the standard of perfect competition) than even concentrated private market structures. Yet, it is also clear that from this perspective the field left to competition law versus other forms of state intervention remains open for negotiation, a negotiation conducted through and according to the rules of the communicating tool of economics. As a result, of a greater recourse to social sciences in public policy, the erosion of traditional divisions of labour and the emergence of risk society, bureaucracy sees also its role change, as it is gradually transformed from a rigid structure performing merely tasks of execution to a more pro-active technocracy, assuming tasks of forecast, knowledge gathering/sharing and communication with the public.

It is important here to reflect on the implications that each form of state intervention, for example antitrust versus regulation, entails to the general claims of expertise and "technicization" that have built bureaucratic legitimacy, on which ultimately rests government's authority to intervene in the marketplace. Ministerial departments and regulators often dispose of superior expertise on the characteristics and problems of the industries they supervise, than competition authorities or courts, which are by essence of generalist nature, dealing ad hoc with a plethora of cases across different sectors. This is due to superior technical skills (for example a telecom regulator understands interconnection better than an antitrust authority), superior expertise and information (as a result of their systematic activity in the sector), but also because of different disciplinary communities and values represented by these regulators, thus capturing a more diverse set of citizens' and consumers' preferences (e.g. environmental regulators often value more the protection of the environment than the protection of competition). In principle, the sector-specific regulators should be better placed to assess the welfare effects of their interventions on consumers and citizens, with the exception, of course, of circumstances where they remain "captured" by the specific interests they are supposed to regulate. However, a similar claim can be made to a certain extent also for competition authorities, thus indicating that from a public choice perspective, the two situations constitute, in practice, functional equivalents. Hence, if there is any claim for an antitrust authority to intervene and control some other form of state activity, this can only happen, under

\footnotetext{
${ }^{33}$ The Causes and Consequences of Antitrust: the Public Choice Perspective (Fred S. McChesney and William F. Shughart II ed. 1995).
} 
this approach of neo-liberalism, because of the superior expertise of the antitrust authority on matters relating to the regulation of markets and competition, in essence economic expertise, or their independence from the other sectors of government bureaucracy. ${ }^{34}$ This is not the place to expand on the important role and continued presence of economists in government bureaucracies, although there are significant differences across jurisdictions that may justify different approaches in the interaction between competition law and government action. ${ }^{35}$ In any case, with the probable exception of public utilities' regulators, competition authorities have been one of the first venues in government bureaucracy, at least in Europe and in the United States, where a high level of economic expertise has been progressively developed, either in house or contracted out to the market of professional experts. Competition authorities claim, on average, more expertise than other government departments in competition law analysis. This configuration should lead to an expansion of the scope of competition law and advocacy, with the exception of instances where the specific industry requires some superior form of economic expertise, which antitrust authorities do not possess, in view of the specific characteristics of the industry. In such rare cases, sector-specific regulation may benefit from antitrust immunity. ${ }^{36}$

In contrast, in the ordoliberal model, competition is a value to be preserved as such, whatever the circumstances and outcomes. This comes out of the constitutional dimension of the principle of market economy. Thus, considerations about the superior technical expertise of government departments and regulators have no place in the analysis of the appropriate scope of competition law intervention versus some other regulatory action. The European Treaties constitute an illustration of this constitutional dimension of the competition principle. Article 3(1)g of the former Treaty of European Communities recognized the vital importance of establishing 'a system ensuring that competition in the internal market is not distorted'. The Court of Justice relied on this provision to apply the principle of competition to State measures in a number of cases. ${ }^{37}$ The Court has placed particular emphasis on Article 3(1)g when confronted with a conflict between competition rules and other EU policies and objectives $^{38}$ and has pronounced, on the basis of this provision, that competition law

\footnotetext{
${ }^{34}$ Inbal Faibish \& Michal Gal, Six principles for limiting Government-Facilitated restrictions on competition, 44 Common Market L Rev 69 (2007).

${ }^{35}$ Marion Fourcade, Economists and Societies: Discipline and Profession in the United States, Britain, and France, 1890s to 1990s (2009).

${ }^{36}$ See, for instance, in the United States, Credit Suisse Securities v. Billing, 551 U.S. 264 (2007) [noting that there is a serious risk that antitrust courts, with different non-expert judges and different nonexpert juries, will produce inconsistent results and mistakes]. Of course, this is not the only source of antitrust immunity of regulation, one could add the dual federalism nature of the US Constitution for the antitrust immunity offered to State regulation.

${ }^{37}$ See, e.g. Case 13/77, SA GB-Inno BM v. Association des détaillants en tabac (ATAB) [1977] ECR 2115, para. 29; C-260/89, Elliniki Radiophonia Tileorasi AE \& Panellinia Omospondia Syllogon Prossopikou v. Dimotiki Etairia Pliroforissis et al. [1991] ECR I-2925, para. 27; Case 229/83, Association des Centres distributeurs Edouard Leclerc v. SARL 'Au blé vert' [1985] ECR 1, para. 9

${ }^{38}$ Case C-67/96, Albany International BV v Stichting Bedrijfspensioenfonds Textielindustrie [1999] ECR I-5751; Case C-309/99, J. C. J. Wouters et al. v. Algemene Raad can de Nederlandse Orde van Advocaten [2002] ECR I-1577.
} 
constitutes a 'fundamental objective of the Community'. ${ }^{39}$ Finally, the Court referred to this article when it granted to national competition authorities the power to set aside provisions of domestic legislation that jeopardize the effet utile of EU competition law. $^{40}$

The existence of a specific provision emphasizing the role of competition law in the text of the "Principles" part of the founding Treaties led to specific implications as to the interpretation of this provision and its relationship with other Community activities. This was reinforced by Article 4 of the Treaty on the European Communities, which was introduced by a Treaty revision in 1992, adding a new joint action of the Community and the member states: the "adoption of an economic policy, which is based on the close coordination of Member States' economic policies [...] and conducted in accordance with the principle of an open market economy with free competition". The scope of the competition principle was thus extended beyond the narrow confines of the competences of the Community (although these were already broadly defined): the member states should also be inspired by this principle in conducting their economic policies. Although Article 3 of the Treaty of the European Union (TEU) does not refer any more to the principle of 'undistorted competition' or "free competition", following the suggestions made by former President Sarkozy of France, Article 3(3) TEU provides that the Union shall establish an internal market with the goal to achieve "a highly competitive social market economy, aiming at full employment and social progress". In addition, according to Protocol n. 27, "the Internal market as set out in Article 3 TEU includes a system ensuring that competition is not distorted". It is too early to assess the impact of the textual modifications introduced by the Treaty of Lisbon, but it seems in general that despite the introduction of the concept of "social market economy" and some horizontal clauses in the European Treaties requiring the consideration of environmental and social policy impacts for Union policies, the principle of free competition remains a primary objective governing all action of the Union. ${ }^{41}$ This constitutional dimension implies that in the presence of a conflict between regulation enacted by the Union or its Member States and the principle of free competition, the latter should take precedence, irrespective of the degree of (economic) expertise of the national or EU bureaucracy implementing the regulation. For example, in subsequent cases, the European Courts have affirmed the absence of any competition law immunity for sector-specific regulation, thus adopting a completely opposite perspective than the US Supreme Court. ${ }^{42}$

\footnotetext{
${ }^{39}$ Case C-289/04P, Showa Denko KK v. Commission [2006] ECR I-5859, para. 55 ; Joined Cases T259-264 and 271/02, Raiffeisen Zentralbank Österreich AG and Others v. Commission [2006] ECR II5169, para. 255

${ }^{40}$ Case C-198/01, Consorzio Industrie Fiammiferi [2003] ECR I-8055, paras. 54-55.

41 On the various interpretative choices offered by the Treaty of Lisbon, see Ioannis Lianos, Competition Law in the European Union after the Treaty of Lisbon, in The European Union after the Treaty of Lisbon 252-284 (Diamond Ashiagbor, Nicola Countouris \& Ioannis Lianos ed., 2012).

${ }^{42}$ See, more recently, Case C-280/08 P, Deutsche Telekom AG v European Commission [2010] ECR I9555. For a commentary, see Javier Tapia \& Despoina Mantzari, The Regulation/Competition
} 
The strategy of integrating the value of competition at all levels of government intervention, because of its constitutional status, had also implications on the organization of the provision of public services across the Member States of the EU. National approaches and styles diverge and are still exercising a powerful symbolic and rhetorical, if not any more legally binding, influence (because of extensive EU harmonization). For example, the French concept of service public has served for a long time as a battle-cry against the expansion of the competition law provisions of the European Treaties to the public sphere, as it has been given, at least subliminally, an organic (service public should be provided by public bodies) versus a material (universal service can be dispensed by public and private bodies) meaning. The slight move towards a less conflicting terminology in the Treaties and secondary legislation, with the concept of "services of general economic interest", cannot dissimulate that tensions remain high. ${ }^{43}$ For the proponents of service public, its domain is mutually excludable from that of competition law, as any expansion of the scope of competition law will lead to an automatic restriction of the scope of service public. The introduction of specific competition law provisions for public undertakings or the recognition of the right of citizens to receive public services illustrate that the two principles as perceived as antagonistic to each other. ${ }^{44}$

On the contrary, the British experience on the interaction of government with the competition principle has been different. The monolithic welfare state that emerged from the Beveridge plan in the 1950s and 1960s was subject to the neoliberal cure of liberalization and privatization during the Thatcher era in the 1980s and to "third way" management in the 1990s and 2000s. A key objective of New Public Management was to achieve a "post-bureaucratic" government, where the introduction of purchaser/provider separation, the creation of quasi-markets, outsourcing and user control would allow multiple forms of provision to be developed in order to create more competition amongst potential providers. ${ }^{45}$ The recent White book Open Public Services of the coalition government in the UK and subsequent legislation adopted or in preparation also aim to introduce consumer choice and

Interaction, in Handbook on European Competition Law, Vol. 2, (forth. Damien Geradin \& Ioannis Lianos ed. 2013). SSRN: http://ssrn.com/abstract=2044722

${ }^{43}$ See, more recently, the adoption of the Services of General Economic Interest Package by the European Commission in April 2012 regarding the conciliation between the competition law provisions of the Treaty and the provision of services of general interest: http://ec.europa.eu/competition/state_aid/legislation/sgei.html.

${ }^{44}$ See, Article 106 TFEU, subjecting public undertakings and undertakings with special or exclusive rights to the application of the general competition law provisions of the Treaty "in so far as the application of such rules does not obstruct the performance, in law or in fact, of the particular tasks assigned to them (services of general economic interest)". Non-market services (compulsory education, social protection, etc.) and sovereign tasks (such as security, justice) are also excluded from the scope of competition law, following the case law of the European Courts. Article 14 of the Treaty on the Functioning of the European Union acknowledges the place occupied by services of general economic interest among the shared values of the Union, thus balancing the constitutional dimension of the competition law provisions. Article 36 of the Charter of Fundamental Rights, now binding, confirms the importance of Article 14 TFEU and acknowledges the need for Union citizens to have access to services of general economic interest.

45 Kenneth Kernaghan, The post-bureaucratic organization and public service values, 66(1) International Review of Administrative Sciences 91 (2000). 
competition in the provision of services by opening public services to a range of providers, not only from the public sector, but also coming from the voluntary and private sector. The White Book goes as far as to declare that "(a)part from those public services where the Government has a special reason to operate a monopoly (e.g. the military) every public service should be open so that, in line with people's demands, services can be delivered by a diverse range of providers". 46 This will be achieved by having suppliers from the private and voluntary sectors entering the public procurement process, providers competing with one another to deliver services directly to individuals armed with personal budgets and entitlements or the power of choice, and the full development of a voluntary, community and social enterprise (VCSE) sector, accountable to local communities, and thus to democratic electoral competition. ${ }^{47}$ Following these proposals, the provision of most government services in the UK would be organized according to the principle of free competition. While the approach does not share the constitutional dimension of the German ordoliberal perspective and its' rules-based approach (it is more outcomes-oriented), they both follow a similar direction.

In conclusion, a bureaucracy-centred theory of competition law and the state interaction will be simultaneously more context aware and empirically focused than current approaches. First, at the macro-level, it becomes important to analyze the value structure foundations on which competition law enforcement is built by looking to the degree of intrusion of neo-liberal values in the design and operation of public powers. Modern bureaucracy is more knowledge-based and outcome oriented than the Weberian description of it as a mere technical, rational, administrative routine-style implementation of public policies decided elsewhere. Second, at the micro-level, the knowledge base, the skills and the disciplinary/professional background of government bureaucracies needs to be explored in depth, before concluding on the appropriate method of interaction with authorities entrusted with the implementation of competition law norms (competition authorities and courts). The level of development of the competition law regime and, of course, the intrinsic quality of government bureaucracies, their sources of wisdom and their ability to produce efficient policies, are also among the elements to take into account.

\section{Case studies on the interaction between the principle of competition and government action in a neo-liberal state}

What are the implications of the transformation of public action in a neoliberal state for the application of competition law to government intervention in markets? To respond to this question, I will examine two case studies illustrating two possible strategies of interaction between the principle of competition and government action in a neo-liberal state. First, the tendency to subject all types of state action to

\footnotetext{
46 HM Governement, Open Public Services - White Paper, July 2011, available at http://www.openpublicservices.cabinetoffice.gov.uk/

${ }^{47}$ Ibid., pp. 39-49.
} 
the discipline of competition may be systematized by the establishment of a prophylactic ex ante competition screening of all proposed laws and regulations. Second, competition in the provision of services of general interest should be adequately managed so as to produce the best possible outcomes from a public policy perspective. Hence, competition may only be introduced for some parameters (e.g. quality) but excluded for others (e.g. price). The traditional analytical framework of competition law will need in this case to be adjusted, to reflect the proper balance between the different aims pursued by government action. The UK managedcompetition system in the healthcare services sector will provide an illustration of how this balancing operates in practice.

\section{A. Introducing competition screening in regulatory impact assessments}

In recent years many countries have introduced the tool of ex ante competition assessment in the process of evaluating draft new laws, regulations or policies. Sometimes, this competition screening is integrated in the general system of regulatory impact assessments; in other cases it has an autonomous existence.

The OECD has prepared a competition checklist, in the context of its "Competition Assessment Toolkit", suggesting a detailed competition analysis of a policy proposal should it have any of the following four effects: (i) setting limits to the number or range of suppliers, (ii) limiting the ability of suppliers to compete, for example by reducing their ability to set prices, advertise or market their goods, or raising their costs, (iii) reducing their incentive to compete by creating a selfregulatory or co-regulatory regime, or increasing transparency over the outputs, prices, sales or costs of the suppliers by requesting the publication of information and (iv) limiting the choices and information available to consumers. ${ }^{48}$ If the proposal affects one of these parameters, a detailed, more comprehensive competition assessment should be undertaken, by looking to the regulatory proposal's impact on the main determinants of competitive pressures for the market in question (e.g. the existence of coordinated effects or reduced incentives to innovation). This assessment involves the definition of a relevant market. The proposed regulatory design should be considered in a comparative context in which alternative means of achieving the regulatory objective that are less restrictive of competition are identified and assessed. If these are not found, then a comparison should be made of the costs and benefits of the proposal, the latter being adopted "only if that comparison shows that, after taking into account the costs of the anti-competitive impact the assessment identified, the proposal's enactment will yield a net benefit". ${ }^{49}$ A similar approach is also taken in other jurisdictions. ${ }^{50}$

\footnotetext{
${ }^{48}$ OECD, Competition Assessment Toolkit, Vol. 1 (2011), pp. 8-9.

${ }^{49}$ Ibid., p. 63.

${ }^{50}$ See, for instance, European Commission, Better Regulation: A Guide to Competition Screening (2005), available at http://ec.europa.eu/competition/publications/legis_test.pdf; OFT 876, Completing competition assessments in Impact Assessments (August 2007), http://www.oft.gov.uk/shared_oft/reports/comp_policy/oft876.pdf .
} 
Some jurisdictions have put in place more general regulatory impact assessment (RIA) procedures in order to examine the impact of proposed regulation and legislation on a number of variables, including economic, social, environmental, and health effects, the competition screening process being, in some cases, cited as one variable among others. For example, the Impact Assessment Guidelines of the European Commission include competition screening as one of the various economic impacts that RIA routinely explore. ${ }^{51}$ This integration of the competition assessment tool into the broader RIA analysis raises questions on the possible links between the two procedures. First, the OECD Competition Toolkit notes that RIA takes a more static approach, comparing likely outcomes based on the existing economic and regulatory environment, while competition assessments are more future oriented, taking a dynamic efficiency approach, and focus on the effects of the proposal on consumer choice, rather than on the economy and public policy in general. ${ }^{52}$ However, it is not clear how different are these tools in practice and how much competition assessment has been integrated in RIA analysis (see Table 1). Competition authorities and courts have already been using cost-benefit analysis techniques in assessing ex post the competitive impact of various forms of regulation. ${ }^{53}$ One could finally argue that competition assessment is based upon competition/Industrial Organization economics methodologies whereas Regulatory Impact Assessments tend to use a broader set of methodologies. Yet, the possibility of cross-fertilization and intensive borrowing between the two techniques should not be underestimated, now that regulatory impact assessments procedures become more systematic at the EU and national levels.

Table 1: The place of competition impact assessments in regulatory impact assessments in the $\mathbf{E U}^{54}$

\footnotetext{
51 European Commission, Impact Assessment Guidelines (January 15, 2009), http://ec.europa.eu/governance/impact/commission_guidelines/commission_guidelines_en.htm ${ }^{52}$ OECD, supra 48, pp. 37-38.

${ }^{53}$ For a recent discussion, see OFT, Article 101(3) - A Discussion of Narrow versus Broad Definition of Benefits (2010), (noting that to the difference of cost benefit analysis techniques employed in RIA, competition authorities do not take a positive view towards aggregation of the costs and benefits across relevant markets. Yet, competition screening, if taken seriously, should lead to the aggregation of costs and benefits across markets in the last step of the analysis, as it was hinted below).

54 I have analyzed 493 summaries from the approximately 690 Regulatory Impact Assessments published at the European Commission website until March 2012.
} 


\section{Competition Assessment in EU's RIAs \\ Total Number oflAs analysed: 690}

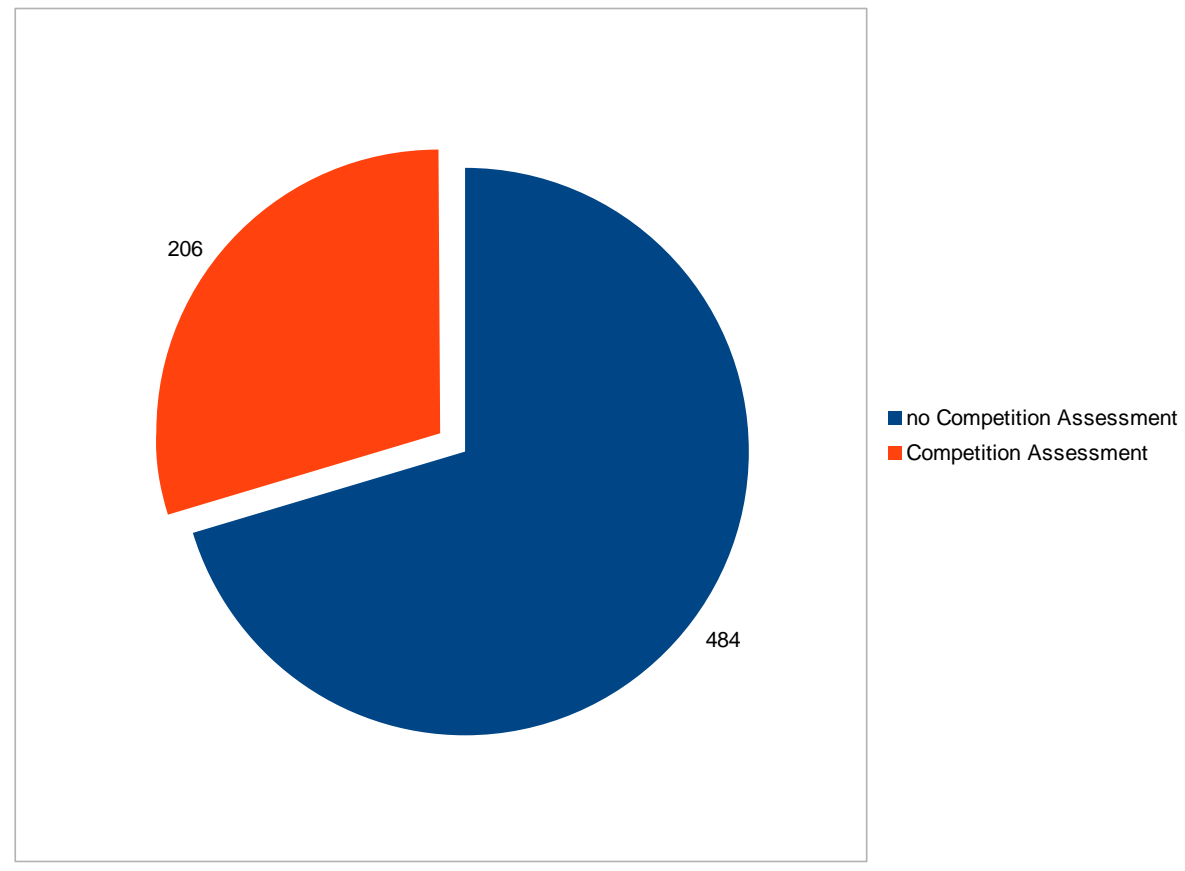

Second, the institutional framework of RIA and that of the competition screening might be different. Although it is recognized that the assessment should be performed by the "frontline" government departments developing the proposal, under the review of an external party, most frequently an Impact Assessment Board, usually these bodies lack, in general, competition expertise. Competition authorities have a role to play: (i) in reviewing any proposal with potential effects on competition (as part of their competition advocacy mission) and making (binding or non binding) recommendations, ${ }^{55}$ (ii) in engaging in ex ante consultations with the "frontline" government department performing the RIA, $^{56}$ (iii) in adopting guidelines for policymakers detailing how competition screening should be performed and integrated in RIAs, ${ }^{57}$ (iv) and in providing advice and training to policy makers at any stage of the process. ${ }^{58}$

Nonetheless, the generalization of the competition screening of draft regulations and laws, as part of the RIA procedures, will inevitably erode the differential of

\footnotetext{
55 The competition assessment may be performed by the competition authority (e.g. UK, Mexico, Korea, Hungary, Greece), or by an independent external authority (e.g. the National Competition Council in Australia).

56 E.g. the procedure provided in Article 63 of the Korean MFTA, according to which other government bodies intending to legislate or amend the laws under their jurisdiction, should ask the KFTC for review of any possible anti-competitiveness of the laws concerned, the KFTC conducting prior-consultation with them. OECD, Korea, para. 63, http://www.oecd.org/korea/39554122.pdf .

${ }^{57}$ See, e.g. OFT 876, Completing competition assessments in Impact Assessments, supra 50.

${ }^{58}$ Ibid., paras 1.2. and 1.3.
} 
expertise from which now benefit competition authorities, in comparison to "frontline" government departments. Once the "culture" of competition assessment is integrated across government bureaucracies, and internal expertise in the form of departmental specialists (lawyers and mainly economists) gets fully developed, the integration of the competition screening in the RIA tool would be complete. Certainly, there are arguments for maintaining an independent institutional voice for competition inside government bureaucracies, but in a neo-liberal State this institutional complexity might not offer much and in, some cases, might even be counterproductive, as the independence of competition authorities might make them ineffective competition advocates, in particular in situation of crisis, hence the need to establish also advocates for competition within and not only outside government bureaucracy. ${ }^{59}$

In conclusion, the integration of competition screening in RIA challenges the view that competition and government action are antithetical to each other and marks the evolution towards a complete integration of the competition principle across government bureaucracies.

\section{B. The emergence of a new style of competition law for government services: managed competition in the healthcare sector in the UK}

The British National Health Service (NHS) was subject to major reforms since the introduction of quasi-markets into the delivery of public services and the separation of the funding and provision role of the state in the national health system in $1989 .{ }^{60}$ This market-oriented approach aimed to reduce costs without public cuts in entitlements. Its main aim was to respond to concerns that NHS bureaucracy was inefficient by introducing competition in the provision of publicly-funded healthcare. When the state acts as a funder, it purchases services from a variety of private, voluntary and public providers, all operating in competition with each other. These "quasi-markets" replace monopolistic state providers with competitive independents ones (initially public providers, and since 2008, private or non-profit ones), but to the difference of conventional markets, on the supply side, the providers competing with each other do not necessarily aim to maximize profits, nor are they privately owned, and on the demand side, purchasing decisions are not made by the patients, but by a third party, acting as an intermediary (in England, since 2011, so called Clinical Commissioning Groups formed by general practitioners (GPs)). In 2006, the government (National Health Service Act) introduced reforms giving patients a choice over where they received care and introduced non-price competition among public hospitals and among the latter and private (also voluntary sector) providers in order to deliver secondary care to publicly funded (through taxation) patients. ${ }^{61}$ Hence,

\footnotetext{
${ }^{59}$ See, Frederic Jenny, Competition Authorities: Independence and Advocacy, in The Global Limits of Competition Law 158-176 (Ioannis Lianos \& Danny Sokol ed., 2012),

${ }^{60}$ Julian Le Grand, Quasi-Markets and Social Policy, 101 The Economic Journal 1256 (1991).

${ }^{61}$ Zack Cooper, The Very English Experience with Competition: Lessons from Britain's National Health Service, OECD, DAF/COMP(2012)9, pp. 313-331.
} 
referred NHS patients (by their GPs) for elective care are offered a choice of four or more providers registered with the Care Quality Commission "willing" to provide services at the NHS (State administered) tariffs. These are based on a prospective payment system, known as Payment by Results $(\mathrm{PbR})$, where the hospital fee is determined by the government on the basis mainly of patients' diagnoses with some other adjustments. Public hospitals are organized, since the Health and Social Care Act 2012, in NHS Foundation Trusts, which benefit from extensive independence from the Department of Health, and are jointly licensed by two independent regulators, Monitor (economic regulator) and the Care Quality Commission (quality standards).

How competition takes place in these "quasi-markets", in view of State funding? As the funding follows patients around the system, introducing patient choice creates financial incentives for providers to compete for market share. ${ }^{62}$ Since a regulator sets the prices, healthcare providers compete over non-price dimensions to attract patients. There is empirical evidence that competition on quality, when the administered price is set at the right level, generates significant benefits for the patients and thus provides better value for money for tax-payers. ${ }^{63}$ As the regulated price is generally set above the providers' marginal costs, the most efficient providers will have the financial incentives to increase the quality of their services, until their profits approach zero. But would a public or non-profit provider be responsive to these financial incentives, at least as a private provider would, if there is no proper profit to be made? Subsequent reforms were necessary in order to enable senior management to be responsive to financial incentives: first, the hospital remuneration was organized in annual block contracts paying for the use of the hospital's facilities for a range of services to predefined populations; second, hospitals were progressively allowed to retain surpluses and their financial situation was subject to central government's control, which still has the power to remove senior management of hospitals in deficit; third, patients should be offered an adequate environment to exercise choice and be responsive to quality signals; fourth, intermediaries such as the Clinical Commissioning Groups, should be also offered financial incentives and autonomy in order to ensure that patients are elastic to quality and exercise their choice diligently. With these reforms, state bureaucracies were subject to the discipline of the competitive process. ${ }^{64}$ Similar reforms have been initiated in various other Member States of the EU.

The introduction of competition and choice in the mixed market of secondary care (where profit and non-profit providers are present), in conjunction with the administered price system, raises the question of the application of competition law in this peculiar setting. It is clear that for competition to work, a broad duty of competitive neutrality should be imposed, encompassing the need to clarify if and

\footnotetext{
${ }^{62}$ Ibid., p. 317.

${ }^{63}$ Martin Gaynor, Reform, Competition, and Policy in Hospital Markets, OECD, DAF/COMP(2012)9, pp. 333-358. Office of Health Economics, Competition in the NHS (January 2012).

${ }^{64}$ Ibid., p. 321, noting that a growing body of empirical research suggests that for profit and non for profit hospitals behave similarly if allowed to retain surpluses.
} 
how competition law may apply in this context. ${ }^{65}$ The issue has generated discussion, in view of the requirement in EU, as well as $\mathrm{UK}$, competition law that the entity to which competition law applies should be an "undertaking": that is an entity exercising an economic activity, the latter concept defining the scope of competition law. ${ }^{66}$ Some authors advance the view that public hospitals providing their services for free and funded by the state should not be considered as "undertakings", and thus competition law should not apply to them, while others argue that they are "undertakings" and competition law applies. ${ }^{67}$

From a legal perspective, there are two problems with the application of competition law in this context: first, the case law of the European Courts provides clearly that where an organisation purchases goods, not for the purpose of offering goods and services as part of an economic activity, but in order to use them in the context of a different activity, such as an activity of a purely social nature, then it is not acting as an undertaking simply because it is a purchaser of those goods. ${ }^{68}$ In this context, the public hospital's services are purchased by the NHS, under the direction of the Department of Health, for the social purpose of providing universal healthcare, funded by tax revenues (a compulsory way of funding). Second, proponents of the application of competition law advance that, at least for some of the health services, public hospitals can potentially make profit, and be qualified as undertakings. ${ }^{69}$ Yet, transposing the concept of "profit" in a non-profit setting is a difficult endeavour. As it was previously explained, the financial incentives provided to public hospitals for inducing them to compete do not relate to monetary profits, but to mainly bureaucratic-related incentives (e.g. the possibility for senior management to keep their position, the aggrandizement of their budget or, since the enactment of the Health and Social Care Act 2012 and its new insolvency provisions treating public and private providers in the same way if they fail, the possibility to keep their public status, as "failed" and debt-hit NHS Foundation Trusts may pass to private management).

At best, there is some ambiguity in the possibility to apply competition law, in which case other principles, public policy or institutional matters may influence the choice of the adequate interpretative option. From a public policy perspective, the non-application of competition law to non-profit hospitals, whereas private providers are subject to it, may introduce an anomaly, at least with regard to the application of the competitive neutrality principle, as public and private providers compete for patients, and private providers are able to make monetary profits. ${ }^{70}$

\footnotetext{
65 OFT1242, Competition in mixed markets: Ensuring competitive neutrality (July 2010), http://www.oft.gov.uk/shared_oft/economic_research/oft1242.pdf

${ }^{66}$ Case C-41/90 Höfner v Macrotron [1991] ECR I-1979.

${ }^{67}$ For a summary of the different positions see Okeoghene Odudu, Are State-owned health-care providers undertakings subject to competition law?, 5 ECLRev 231 (2011).

${ }^{68}$ Case C-205/03 P, Fenin v. Commission [2006] ECR I-6295.

${ }^{69}$ Odudu, op. cit., p. 236.

70 See, the profit structure deal signed with the transfer of the Hichinbrooke's public hospital management to Circle, a private firm co-owned by doctors: http://www.bbc.co.uk/news/uk-england-
} 
However, from an institutional perspective, enforcing general competition law in this context might be problematic.

First, competition authorities and (to a certain degree courts) with the mandate to enforce competition law, have expertise in applying competition law principles but no expertise or mandate on issues relating to the health and safety of patients. Their mission-oriented role--preserving the competitive process--may also influence their setting of priorities between the value of competition and other values, such as integrated care, which might be of importance to patients. As a recent OECD secretariat report reminds us, the competitive process allows an efficient allocation of resources, irrespective of the underlying set of preferences. Yet it might also result in undesirable outcomes with regard to the care received by patients. ${ }^{71}$ Hence, it should be considered as an instrument for the provision of high quality healthcare, rather than as an end in itself.

Second, the provision of effective healthcare requires the cooperation of different providers across but also at the same level of the healthcare chain. In order to ensure a seamless health service to patients and economies to the taxpayer, providers and commissioners must exchange the necessary information about ways to improve patient safety and joint research and development. Joint purchasing and cooperation may also sometimes be necessary in order to disseminate and launch innovations faster. In a competitive and segmented healthcare market, there is a risk that care will be fragmented and that one provider will not always know what another provider has done, leaving the patients to sort out how and when to deal with different providers for different elements of their care. Cooperation between providers is thus essential for enabling integrated care.

Due to their generalist nature, competition authorities or courts are not, however, well placed to develop the technical expertise and acquire necessary information to guarantee the preservation of integrated care, nor are they generally ready to accept that cooperation might in some cases be more important than competition. It thus becomes essential to entrust the application of competition law principles to a sectorspecific regulator. In the UK, Monitor has extensive competence in ensuring the right balance between cooperation and competition, with the assistance of the Competition and Cooperation Panel. The new Health and Social Care Act 2012 makes clear that Monitor's core duty is that patient interests always come first and that where an integrated service raises competition concerns, Monitor will focus on what benefits patients, its role being to ensure that the benefits to patients outweigh any negative effects to competition, and that any negatives are kept to a minimum. ${ }^{72}$

Finally, the concept of "restriction of competition" in the healthcare quasi-markets and the cost-benefit analysis to be performed differ from those employed in competition law. First, the restriction of competition relates to harm to patients

cambridgeshire-16812998, according to which, if Circle succeeds in reversing the debt-hit hospital's fortunes then it will receive a pre-defined part of the yearly surplus.

${ }^{71}$ OECD, Secretariat, Competition in Hospital Services - The Policy Dimension, DAF/COMP(2012)9, pp. 23-67, p. 28.

${ }^{2}$ Clauses 62(4) and 66 of the Health and Social Care Act 2012. 
(reduced patient choice for NHS-funded services) and taxpayers from lower quality services, although in some limited circumstances they might also have some effect on prices, for non-routine elective services. ${ }^{73}$ Second, benefits to be taken into account in order to outweigh the existence of a "restriction of competition" in this sector do not always take the form of the usual cost and quality efficiency gains of competition law. Certainly, economies of scale and scope lowering short-run variable costs, the increase of patient volumes (the "output" to maximize) or procedures reducing transaction costs are benefits to consumers that are usually taken into account in general competition law. But other factors, such as improved recruitment and retention of staff, better information, shared clinical working practices or seamless patient care might not be easily transposable in the context of general competition law. It becomes therefore clear that a different institutional and/or, to some extent, substantive law setting is needed in order to enforce competition law principles in this peculiar setting.

For this reason, prior to the Health and Social Care Act 2012, the UK made the choice of a specific competition law regime, applying to all commissioners and providers of NHS-funded services, irrespective of whether they are public, private or third sector organizations. These Principles and Rules for cooperation and competition (PRCC) are not legally binding provisions enforceable by courts; they are inspired by general competition law, but at the same time emphasize a number of other parameters of essence for the promotion of competition in these quasi-markets, such as rules for the commissioning and procurement of health services, the transparency and fairness of the payment regimes, the duty of commissioners and providers to cooperate in order to deliver seamless and sustainable care to patients, or rules regulating promotional activity. A Competition and Cooperation Panel (CCP) was also set to provide advice on matters of compliance with the PRCC and has since adopted extensive guidelines on the interpretation of the PRCC with regard to conduct and merger cases. ${ }^{74}$

Following the enactment of the Health and Social Care Act 2012, the CCP will be integrated in Monitor, the healthcare economic regulator, which is also entrusted with the power to apply general competition law concurrently with the Office of Fair Trading (OFT). Hence, general competition law will apply to the health care sector, although through a different institutional framework than non-regulated sectors with the concurrent jurisdiction of both the sector economic regulator and the competition authority. ${ }^{75}$ How would the interaction between these two competition authorities work in practice? The broad duties of the Monitor will inevitably weight in the

\footnotetext{
${ }^{73}$ Routine elective services are paid for at a uniform national tariff for each procedure (subject to local flexibilities), so there is little scope for some forms of price related anticompetitive activity (pricefixing by providers). However, for other services, the price paid may be determined by negotiation or a competitive tender, in which case there might be scope for price fixing.

74 Cooperation and Competition panel, Conduct Guidelines (October 2010), http://www.ccpanel.org.uk/content/Conduct_Guidelines.pdf ; Cooperation and Competition panel, Merger Guidelines (October 2010), http://www.ccpanel.org.uk/content/Merger_Guidelines.pdf

${ }^{75}$ As a result of these modifications, the PRCC will not apply as such, general competition law will, but it will be certainly integrated in
} 
decision-making process and may lead to different outcomes than a situation where the OFT would be involved on its own. ${ }^{76}$ Focusing on the different values, competences and methodologies used by the respective bureaucracies and on how these could complement each other in the enforcement of competition law in this sector might offer a better predictive tool of their interaction than a normative theory on the relations between sector-specific regulators and competition authorities or courts. In a neo-liberal state, where competition is a value underpinning any form of state action, the exact place of other values becomes a matter for continuous negotiation between different segments of public bureaucracy. These rely on their expertise/epistemic competence on the substantive issues of the policy area to which they intervene, rather than on their general bureaucratic competence or procedures and administrative routines, as would have been the case in the traditional (Weberian) view of bureaucracy. For example, the $C C P$ relies in its decision-making process on the input of two groups of experts: the clinical reference group, composed by experts in public health and medicine, which provide advice on health and safety issues, and the economics reference group, comprising experts in health economics and competition, consulting on competition economics and analytical techniques/methodologies. This expertise is more extensive than that usually received by competition authorities (which mainly focus on the economics of industrial organization) $)^{77}$.

\section{The need for a comparative institutional analysis}

In essence, it becomes necessary to conduct a comparative institutional analysis ${ }^{78}$ focusing on the respective expertise, among other criteria, of each bureaucracy (competition authority or sector specific regulator) before concluding on the appropriate interaction between these different institutions. Ministerial departments, sector-specific regulators and competition authorities constitute all imperfect alternatives, the question being which alternative is best (for welfare - the underlying aim of state intervention in a neo-liberal state), given the real world of high information cost and the fragmentation of expertise (over different dimensions of welfare). The tool of comparative institutional analysis provides some solution to this choice between imperfect alternatives.

\footnotetext{
${ }^{76}$ To some extent the UK model constitutes a step in a continuum moving from the non-application of competition law, to the application of competition law-inspired principles, to the enforcement of general competition law by a sector-specific regulator (in conjunction with the competition authority) and to the application of general competition law by the regular institutional mechanism (albeit with some guidance on the way this will be applied). The last model is that followed in the US: Statements of the USDOJ and the FTC on antitrust enforcement policy in healthcare, http://www.ftc.gov/bc/healthcare/industryguide/policy/index.htm .

${ }^{77}$ For an interesting comparative analysis of the different origins, regulatory tools, composition and role sets of regulatory authorities, see Tony Prosser, The Regulatory Enterprise - Government, Regulation and Legitimacy (OUP, 2012).

${ }^{78}$ For an account of a comparative institutional analysis of public and private bureaucracies using transaction costs economics see, O. Williamson, Public and Private Bureaucracies: A Transaction Cost Economics Perspective, 15(1) JLEQ 306.
} 
This is particularly the case in the UK, where sector specific regulators proceed to a concurrent application of competition law, along with their other duties and hence making an institutional choice does not amount to a choice between regulation and competition law. Both can be efficiently combined. Hence, the efficacy of the competition authority should not be presumed for all regulatory "transactions" aiming to promote competition and welfare, but be subject to a comparative analysis of alternative institutions, some of which are sector specific regulators or self-regulatory bodies. The possibility of capture should of course be factored in the comparative institutional analysis, yet its effect should not be overestimated. As Oliver Williamson has rightly observed, "even if the benefits of regulation decline over time and go negative, the discounted present value may remain positive" ${ }^{\text {"79 }}$. The proximity of the goals of sector specific regulators to those of government departments (as they are by definition wider than the simple preservation of a competitive market, which is the main task of a competition authority) may enable some degree of economization of administrative and regulatory costs, following the integration of different goals within a unified framework of rules or standards for undertakings to comply with. Quite often the tasks of ministerial departments or sector specific regulators are not only to regulate market failures or market imperfections (which is close to the tasks performed by competition authorities), but also to proceed to some re-distributional transactions (e.g. public service obligations), the latter being a highly politicized area of government activity. One would expect that the information asymmetries, with regard to the political/strategic objectives pursued by the government or legislature, would be lower for ministerial departments and sector-specific regulators than it would be the case for competition authorities, hence providing some advantages to the first two in the comparative institutional analysis.

A "participation-centered" approach, as it has been advanced in some accounts of comparative institutional analysis ${ }^{80}$, will not commit the fallacies of one-sided interest group analysis to only focus on the risk of over representation of minority interests seeking rents, but it will search for all affected groups in various dimensions and will examine how the distribution of benefits and costs of action would affect the ability of different groups to get what they want via the different institutions. From this perspective, the over-representation of some majority interests (e.g. consumers) might also lead to unsatisfactory results from the point of view of welfare and should not be overlooked. According to this theory, it is important to focus on the factors determining a group's marginal cost of participation. In Komesar's "participationcentered" model, "information costs" and "organization costs" determine a group's participation costs ${ }^{81}$. The first refer to the costs of learning the law and procedures applicable as well as the costs for the specific institution to gather information. In view of the almost continuous relation between sector specific regulators and

\footnotetext{
${ }^{79}$ Ibid., p. 318.

${ }^{80}$ Neil Komesar, Imperfect Alternatives: Choosing Institutions in Law, Economics and Public Policy (Univ. of Chicago Press, 1994).

${ }^{81}$ Ibid., p. 8.
} 
regulated undertakings and the amount of information provided by the latter to the former, in order to assist the sector specific regulator in its price setting function, the costs of gathering information are lower for sector-specific regulators than it is the case for competition authorities. Assuming that the costs of learning the law and procedures applicable are similar, sector-specific regulators may have some comparative advantages.

The organization costs facing a group are the costs to be incurred by the members who want to take action, and want other members to contribute. Organization costs increase with group size. The size of each member's individual stake - how much she stands to gain from winning - also affects her inclination to organize her fellow members. It follows that organization costs rise as individual stakes decrease. The dispute resolution can thus be biased in two ways: a "minority bias" when a small group with high individual stakes convinces an institution to enact its preferred policy and by doing so inflicts a greater cost on a large group with lower individual stakes than the benefit it obtains 82 , or a "majoritarian bias" when a large group with low individual stakes prevails and thereby inflicts a greater cost on a small, high-stakes group than the benefit it obtains ${ }^{83}$. Once a dispute has been identified, the goal of comparative institutional analysis is thus to find the institution least likely to develop a minority or majoritarian bias, that is, the institution where the group with the highest total stake is most likely to win.

In conclusion, current accounts of the interaction between competition law and state activities are based on a clear-cut old liberalism style distinction between "state"/"government" and "market", which do not take into account the emergence of the neo-liberal state. By doing so, they also ignore the multi-faceted nature of the concept of "state", and the important inputs of political science and sociological literature on the different forms of state and the role of public bureaucracies. By advancing a "bureaucracy theory" of the competition law and the state interaction, based on the use of the tool of comparative institutional analysis, this chapter aims to offer an alternative inter-disciplinary theoretical framework that can be successfully transposed into different institutional and cultural settings.

\footnotetext{
${ }^{82}$ Ibid., p. 55.

${ }^{83}$ Ibid., p. 77.
} 